\title{
STUDIES ON AMINO ACID METABOLISM. II. BLOOD GLYCINE AND TOTAL AMINO ACIDS IN VARIOUS PATHOLOGICAL CONDITIONS, WITH OBSERVATIONS ON THE EFFECTS OF INTRAVENOUSLY ADMIN- ISTERED GLYCINE ${ }^{1}$
}

\author{
By A. de VRIES ${ }^{2}$ AND B. ALEXANDER, with the technical assistance of Y. QUAMO \\ (From the Medical Research Laboratory, Beth Israel Hospital, and the Department of Medicine, \\ Harvard Medical School, Boston)
}

(Received for publication January 16, 1948)

\section{INTRODUCTION}

Glycine plays a role in the metabolism of serine (1), glutamic acid (2), glyoxylic acid (3), uric acid (4-6), lactate $(6)$, creatine (7), glutathione $(8)$, and the porphyrin of hemoglobin $(9,10)$. The amino acid has been administered, with inconclusive results, to patients with myasthenia gravis $(11,12)$, and with peripheral vascular disorders because of its vasodilating effects (13). Moreover, knowledge of the life span of erythrocytes (14) and of red cell destruction (15) has been advanced by using tagged glycine.

The normal concentration of glycine in blood, plasma, and erythrocytes has been reported (16) but nothing is known regarding its level in pathological conditions. The present data consist of glycine and total $\alpha$ amino $\mathrm{N}$ levels in patients with various diseases and following infusions of the amino acid.

\section{METHODS}

Glycine and total $\alpha$ amino $\mathrm{N}$ were measured by techniques previously described $(17,18)$. Each value is the average of duplicate determinations.

For the glycine tolerance tests, a sterile 10 per cent aqueous glycine solution (Eastman) was injected at 30 cc. per minute (total amount-1 gm. of the amino acid per 15 lbs. of body weight). In three subjects less glycine was administered. Blood glycine was determined before, and at intervals after, the injection. The urinary excretion of glycine during the experiments was also measured. Food was withheld for 12 hours prior to, and throughout, the test, but water was permitted ad libitum.

\section{RESULTS}

Normals: Based on previous data (16) and a few additional observations on normal subjects,

1 Supported by a grant from the John and Mary Markle Foundation.

2 Aided by Fellowships from the Rothschild Hadassah University Hospital, Jerusalem, and from the Dazian Foundation, New York. the normal glycine range is now considered to be: for blood, 1.76-3.02 mgm. \% (mean 2.10; S. D. 0.26 ) ; for plasma, 1.47-2.83 (mean 1.87 ; S. D. 0.34 ) ; for red cells, $1.64-3.73$ (mean 2.49 ; S. D. 0.51 ). Any value for glycine or $\alpha$ amino $\mathrm{N}$ which deviated from the normal mean by an amount exceeding twice the standard deviation was considered significantly abnormal. ${ }^{\mathrm{z}}$

Diseases of the liver and bile ducts: Five of 11 patients with liver disease had jaundice of hepatocellular origin; in two others the jaundice was either obstructive or hepatocellular. Subnormal blood and plasma glycine were found in one subject (subacute yellow atrophy [Table I, No. 10]) while in another (acute infectious hepatitis [No. 14]) plasma glycine was low whereas whole blood glycine was normal. Erythrocyte glycine was significantly elevated in five, contributing in four to a high whole blood glycine. These individuals had definite evidence of parenchymatous involvement.

Case P. L. with severe liver damage (Table I, Nos. 10-13) is of particular interest. Although determinations were not done until high protein feeding by stomach tube had already been initiated (with clinical improvement), blood and plasma glycine and total $\alpha$ amino $N$ values were extremely low. As the patient continued to improve, plasma glycine and blood $\alpha$ amino $N$ returned to normal while red cell glycine became abnormally high.

In two cases of liver disease, an intravenous glycine tolerance test was essentially normal.

Elevated red cell amino $\mathrm{N}$ was observed in three patients in one of whom plasma $\alpha$ amino $N$ was also increased. No correlation between glycine, $\alpha$ amino $\mathrm{N}$ and protein concentration was evident.

\footnotetext{
3 In order to conserve space, only subjects who showed abnormal glycine values are recorded in Tables I and II. Should the reader desire additional data he may communicate with the authors.
} 
Thus, except for low glycine and amino $\mathrm{N}$ in one case of subacute yellow atrophy, returning to normal with clinical improvement, no remarkable findings in plasma glycine were observed. Noticeable, however, was the tendency to elevated glycine and $\alpha$ amino $\mathrm{N}$ in the red cells.
Diseases of the kidney and essential hypertension: In two patients with acute glomerulonephritis the glycine values were normal, despite azotemia. Of nine subjects with chronic glomerulonephritis and renal insufficiency glycine concentrations were significantly increased in six and appeared unre-

TABLE I

Blood glycine and $\alpha$ amino $\mathrm{N}$ in various diseases

\begin{tabular}{|c|c|c|c|c|c|c|c|c|c|c|c|c|}
\hline \multirow{2}{*}{ No. } & \multirow{2}{*}{ Subject } & \multirow{2}{*}{ Date } & \multicolumn{3}{|c|}{ Amino $\mathrm{N}$} & \multicolumn{3}{|c|}{ Glycine } & \multirow{2}{*}{$\begin{array}{l}\text { Ict. } \\
\text { ind. }\end{array}$} & \multirow{2}{*}{$\begin{array}{l}\text { Total } \\
\text { prot. }\end{array}$} & \multirow{2}{*}{ Alb. } & \multirow{2}{*}{ Glob. } \\
\hline & & & Blood & Plasma & \begin{tabular}{|c|} 
Eryth- \\
rocytes
\end{tabular} & Blood & Plasma & $\begin{array}{c}\text { Eryth- } \\
\text { rocytes }\end{array}$ & & & & \\
\hline
\end{tabular}

Diseases of the liver and bile ducts

\begin{tabular}{|c|c|c|c|c|c|c|c|c|c|c|c|c|c|}
\hline $\begin{array}{l}10 \\
11 \\
13 \\
14 \\
16 \\
18 \\
24 \\
28\end{array}$ & $\begin{array}{l}\text { P. L. } \\
\text { P. L. } \\
\text { P. L. } \\
\text { A. E. } \\
\text { L. S. } \\
\text { L. S. } \\
\text { J. R. } \\
\text { R. H. }\end{array}$ & $\begin{array}{l}2 / 26 / 46 \\
3 / 2 / 46 \\
3 / 25 / 46 \\
1 / 12 / 47 \\
2 / 6 / 47\end{array}$ & $\begin{array}{l}\text { Sub yel. atrophy } \\
\text { Sub yel. atrophy } \\
\text { Sub yel. atrophy } \\
\text { Infect. hepatitis } \\
\text { Infect. hepatitis } \\
\text { Infect. hepatitis } \\
\text { Cirrhosis; jaundice } \\
\text { Chr. hepatit.; ? malignancy }\end{array}$ & $\begin{array}{l}\text { mgm. } \\
\% \\
2.63 \\
4.49 \\
4.88 \\
5.13 \\
9.20 \\
5.94 \\
3.92\end{array}$ & $\begin{array}{l}\text { mgm. } \\
\% \\
2.69 \\
3.05 \\
3.30 \\
3.42 \\
7.60 \\
4.42 \\
\\
2.78\end{array}$ & $\begin{array}{c}\text { mgm. } \\
\% \\
2.50 \\
7.30 \\
7.45 \\
10.20 \\
12.00 \\
7.05 \\
6.24\end{array}$ & $\begin{array}{l}\text { mgm. } \\
\% \\
1.64 \\
2.62 \\
3.03 \\
2.10 \\
3.40 \\
2.87 \\
3.07 \\
2.95\end{array}$ & $\begin{array}{l}\text { mgm. } \\
\% \\
1.17 \\
1.67 \\
2.26 \\
1.35 \\
2.19 \\
2.06 \\
1.98 \\
2.33\end{array}$ & $\begin{array}{l}\text { mgm. } \\
\% \\
2.63 \\
4.46 \\
4.29 \\
4.36 \\
5.55 \\
3.99 \\
4.43 \\
4.21\end{array}$ & $\begin{array}{r}49 \\
31 \\
15 \\
17 \\
55 \\
26 \\
34 \\
6\end{array}$ & $\begin{array}{c}\text { gm. } \\
\% \\
5.41 \\
7.07 \\
5.90\end{array}$ & $\begin{array}{l} \\
2.78 \\
3.32\end{array}$ & $\begin{array}{l}3.54 \\
3.47 \\
5.08\end{array}$ \\
\hline
\end{tabular}

Renal disease and essential hypertension

\begin{tabular}{|c|c|c|c|c|c|c|c|c|c|c|c|c|}
\hline $\begin{array}{l}33 \\
34 \\
35 \\
36 \\
39 \\
41 \\
43 \\
44 \\
47 \\
49\end{array}$ & $\begin{array}{l}\text { N. S. } \\
\text { I. C. } \\
\text { I. Z. } \\
\text { J.Z. Z. } \\
\text { M. K. } \\
\text { E. W. } \\
\text { M. C. } \\
\text { J. M. } \\
\text { R. R. } \\
\text { B. F. }\end{array}$ & $\begin{array}{l}\text { Chr. glomerul.; osteoporosis } \\
\text { Chr. glomerul.; uremia } \\
\text { Chr. glomerul.; uremia hypert. } \\
\text { Chr. glomerul.; uremia hypert. } \\
\text { Hypert.; urem.; myocard. infarct. } \\
\text { Uremia; sulfadiazine kidney } \\
\text { Chr. glomerul.; nephrosis; uremia } \\
\text { Chr. glomerul.; nephrosis; diab. } \\
\text { Hyperten.; diabetes } \\
\text { Essential hypertension }\end{array}$ & $\begin{array}{l} \\
4.72 \\
5.02 \\
5.81\end{array}$ & $\begin{array}{l}5.14 \\
3.99 \\
3.86 \\
\\
3.14 \\
\\
3.86 \\
4.80\end{array}$ & $\begin{array}{r}8.58 \\
16.30 \\
\\
10.30 \\
7.09 \\
7.07\end{array}$ & $\begin{array}{l}3.56 \\
3.08 \\
2.58 \\
2.96 \\
2.24 \\
2.48 \\
3.53 \\
2.71 \\
2.69 \\
2.65\end{array}$ & $\begin{array}{l}3.64 \\
3.04 \\
2.11 \\
2.96 \\
1.72 \\
2.95 \\
3.00 \\
1.62 \\
2.31 \\
2.06\end{array}$ & $\begin{array}{l}3.25 \\
3.19 \\
3.91 \\
\\
3.57 \\
1.34 \\
5.40 \\
4.28 \\
3.36 \\
3.39\end{array}$ & $\begin{array}{r}\text { NPN } \\
\text { mgm. } \\
\% \\
45 \\
75 \\
97 \\
166 \\
150 \\
96 \\
50 \\
34 \\
35 \\
37\end{array}$ & $\begin{array}{l}6.63 \\
6.70 \\
7.01 \\
7.01 \\
\\
5.24 \\
4.04 \\
5.69 \\
6.10 \\
7.89\end{array}$ & $\begin{array}{l}3.99 \\
1.82 \\
3.59\end{array}$ & $\begin{array}{l}3.02 \\
2.22 \\
2.10\end{array}$ \\
\hline
\end{tabular}

Endocrine diseases

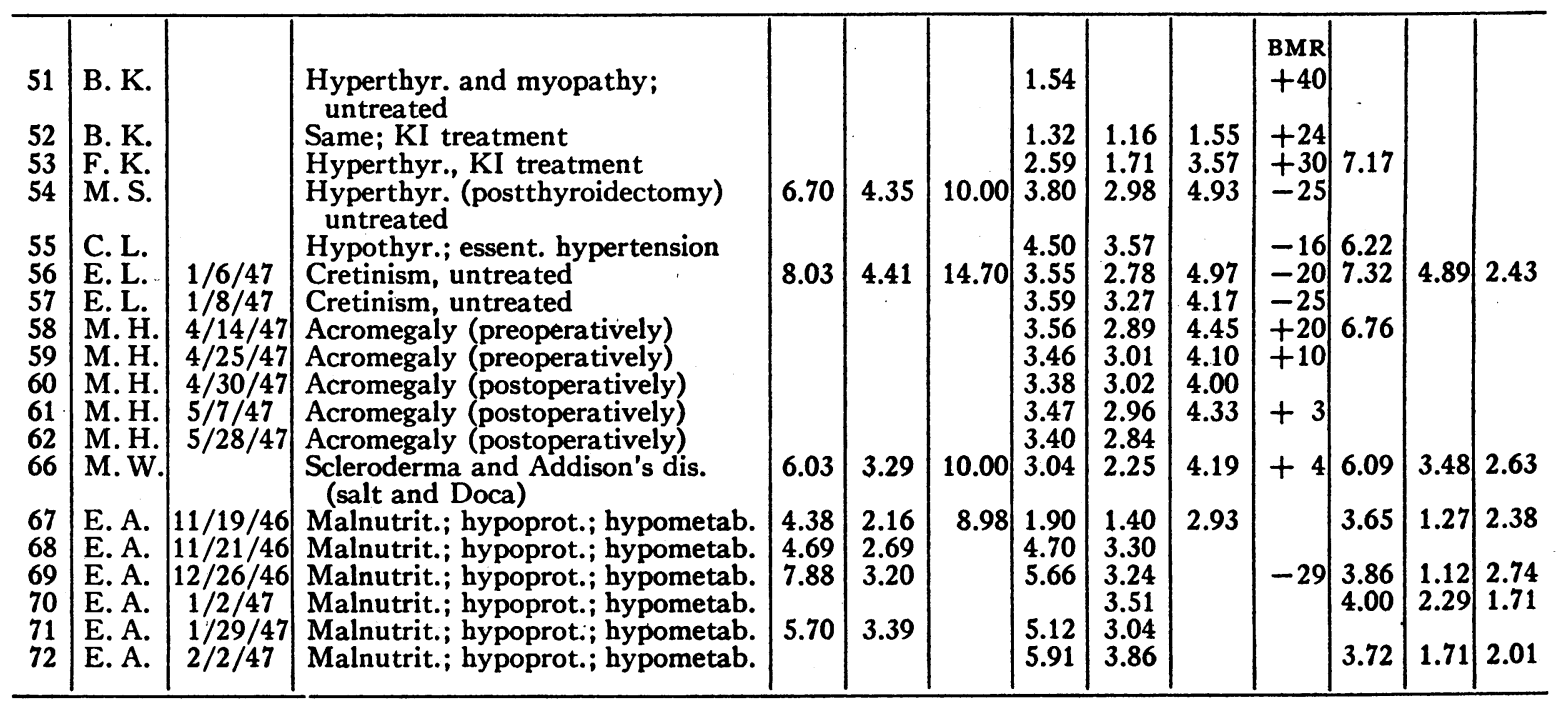


TABLE I-Continued

\begin{tabular}{l|l|l|l|l|l|l|}
\hline No. Subject & Date & & Amino N & \multicolumn{2}{|c|}{ Glycine } \\
\hline
\end{tabular}

Diseases of muscle

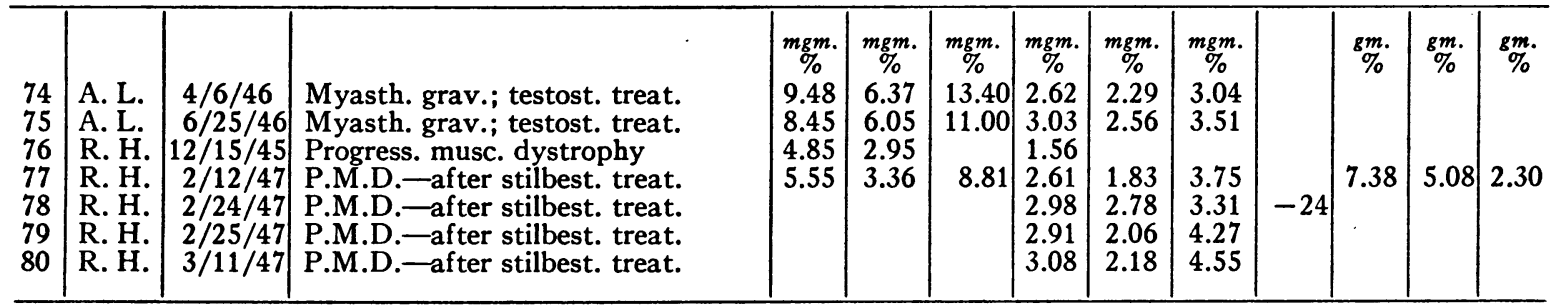

Diseases of skin

\begin{tabular}{l|l|l|l|l|l|l|l|l|l|l|l|l|l}
\hline 81 & E. G. & & $\begin{array}{l}\text { Pemphigus; treat. w/nirvanol } \\
\text { 8upus ery them. dissem. }\end{array}$ & 8.00 & 4.62 & 14.80 & 3.62 & 2.29 & 6.63 & & 6.43 & & \\
A. D. & E. C. & & & & & 2.50 & 1.67 & 4.11 & +11 & 5.66 & 2.63 & 3.03 \\
& & & & & & & \\
\hline
\end{tabular}

Blood diseases

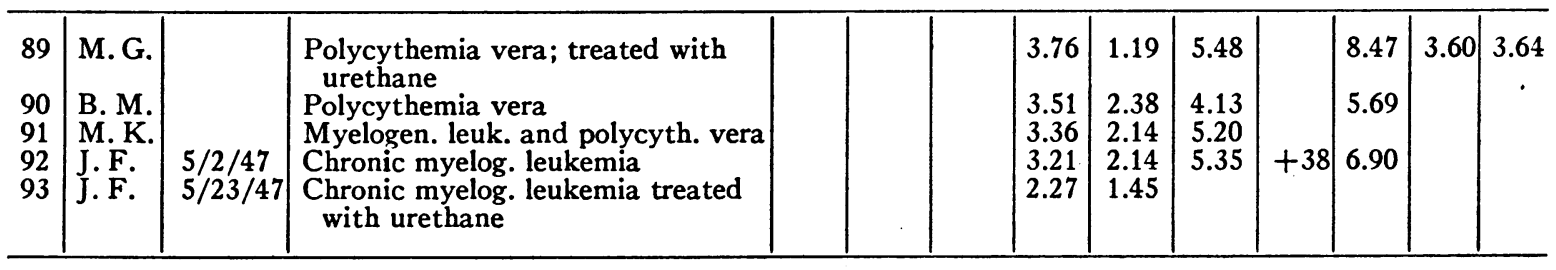

Miscellaneous

\begin{tabular}{|c|c|c|c|c|c|c|c|c|c|c|c|c|}
\hline $\begin{array}{r}94 \\
96 \\
99 \\
103 \\
106 \\
107 \\
118 \\
119 \\
123 \\
124 \\
127 \\
129\end{array}$ & $\begin{array}{l}\text { G. F. } \\
\text { G. F. } \\
\text { O. K. } \\
\text { I. R. } \\
\text { M. Z. } \\
\text { A. B. } \\
\text { P. Y. } \\
\text { P. Y. } \\
\text { P. Y. } \\
\text { P. Y. } \\
\text { J. B.* } \\
\text { S. T.* }\end{array}$ & $\begin{array}{l}3 / 28 / 47 \\
4 / 4 / 47 \\
4 / 23 / 47 \\
4 / 24 / 47\end{array}$ & $\begin{array}{l}\text { Rupt. interverteb. disc } \\
\text { Rupt. interverteb. disc } \\
\text { Bronchial asthma } \\
\text { Carc. pancreas; metast. } \\
\text { Chr. ulc. colitis; malnut. } \\
\text { Chr. ulc. colitis; malnut. } \\
\text { Rheumat. arthritis } \\
\text { Rheumat. arthritis } \\
\text { Rheumat. arthritis } \\
\text { Rheumat. arthritis } \\
\text { Rheumat. arthritis } \\
\text { Rheumat. arthritis }\end{array}$ & 4.62 & 2.95 & 7.41 & $\begin{array}{l}2.62 \\
2.69 \\
2.79 \\
2.78 \\
1.77 \\
1.56 \\
1.37 \\
1.65 \\
1.85 \\
1.98 \\
2.86 \\
1.69\end{array}$ & $\begin{array}{l}2.08 \\
1.83 \\
1.98 \\
1.99 \\
1.19 \\
1.61 \\
1.11 \\
0.96 \\
1.04 \\
1.10 \\
1.72 \\
1.15\end{array}$ & $\begin{array}{l}3.78 \\
4.48 \\
3.68 \\
4.10 \\
2.37 \\
1.41 \\
1.91 \\
3.27 \\
3.88 \\
4.05 \\
4.80 \\
2.67\end{array}$ & $\begin{array}{l}6.05 \\
6.53 \\
4.32 \\
\\
7.34\end{array}$ & 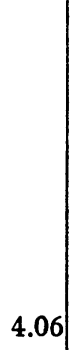 & 3.28 \\
\hline
\end{tabular}

* We are indebted to Dr. Walter Bauer and Dr. Louis K. Dahl of the Massachusetts General Hospital, Boston, for generously providing these patients for our study.

lated to the degree of nitrogen retention and to $\alpha$ amino $N$ which, except in two cases, was normal. The glycine tolerance test was not remarkable in two subjects with chronic nephritis, one with marked hypoproteinemia.

Endocrine disease: Five patients with hypermetabolism were studied. In one (No. 51) who showed myopathy simulating myasthenia gravis, all the glycine values were low. In another subject with acromegaly (Nos. 58-62) the values were elevated ; this persisted for at least one month after ablation of the hypophysis. Blood amino $\mathrm{N}$ was normal in those subjects in whom it was determined.

In five cases of hypometabolism, glycine tended to be elevated, whereas in only one, a cretin (No. 56 ), was the $\alpha$ amino $N$ also increased. In one patient with hypometabolism and nutritional hypoproteinemia plasma amino $\mathrm{N}$ was originally low, then steadily rose, while plasma glycine values 
TABLE II

Intravenous glycine tolerance test

\begin{tabular}{|c|c|c|c|c|c|c|c|c|c|c|}
\hline \multirow{2}{*}{ No. } & \multirow{2}{*}{ Init. } & \multirow{2}{*}{ Sex } & \multirow{2}{*}{ Diagnosis } & \multirow{2}{*}{ Wt. } & \multirow{2}{*}{$\underset{\text { given }}{\text { Glycine }}$} & \multirow{2}{*}{$\begin{array}{c}\text { Time } \\
\text { after glyc. }\end{array}$} & \multicolumn{3}{|c|}{ Blood glycine } & \multirow{2}{*}{$\begin{array}{l}\text { Glycine } \\
\text { excret. }\end{array}$} \\
\hline & & & & & & & Blood & Plasma & Cells & \\
\hline 5 & C. L. & $\mathbf{F}$ & $\begin{array}{l}\text { Essent. hyperten. } \\
\text { hypothyroid. }\end{array}$ & $\begin{array}{l}\text { lbs. } \\
210\end{array}$ & $\begin{array}{c}\text { gms. } \\
14\end{array}$ & $\begin{array}{r}\min . \\
0 \\
20 \\
80 \\
140 \\
260\end{array}$ & $\begin{array}{c}m g m . \% \\
4.50 \\
26.7 \\
12.7 \\
9.99 \\
7.87\end{array}$ & $\begin{array}{c}m g m . \% \\
3.57 \\
32.2 \\
12.8 \\
9.20 \\
7.27\end{array}$ & $\begin{array}{c}m g m . \% \\
6.08 \\
17.4 \\
12.4 \\
11.4 \\
8.89\end{array}$ & $\begin{array}{l}m g m . \\
277\end{array}$ \\
\hline 6 & M. H. & F & $\begin{array}{l}\text { Acromegaly (one week } \\
\text { postoperatively) }\end{array}$ & 150 & 9 & $\begin{array}{r}0 \\
20 \\
80 \\
200\end{array}$ & $\begin{array}{c}3.42 \\
15.9 \\
9.81 \\
6.79\end{array}$ & $\begin{array}{c}2.96 \\
20.7 \\
11.2 \\
6.23\end{array}$ & $\begin{array}{l}4.33 \\
7.82 \\
7.52 \\
7.74\end{array}$ & 614 \\
\hline 7 & E. A. & F & $\begin{array}{l}\text { Nutrit. hypoprot.; } \\
\text { hypometabolism }\end{array}$ & 76 & 5 & $\begin{array}{r}0 \\
20 \\
80 \\
140 \\
200\end{array}$ & & $\begin{array}{c}3.51 \\
32.6 \\
11.1 \\
7.49 \\
4.99\end{array}$ & & 34 \\
\hline 10 . & P.Y. & $\mathbf{M}$ & Rheumatoid arthritis & 121 & 8 & $\begin{array}{r}0 \\
20 \\
80 \\
200\end{array}$ & $\begin{array}{l}1.87 \\
5.88 \\
2.96 \\
2.61\end{array}$ & $\begin{array}{l}1.28 \\
5.54 \\
2.14 \\
1.36\end{array}$ & $\begin{array}{l}3.25 \\
6.07 \\
4.91 \\
5.58\end{array}$ & \\
\hline 11 & P.Y. & $\mathbf{M}$ & $\begin{array}{l}\text { Rheumatoid arthritis, } \\
30 \text { gms. glycine orally } \\
12 \text { hours before test }\end{array}$ & 121 & 8 & $\begin{array}{r}0 \\
20 \\
80 \\
200\end{array}$ & $\begin{array}{l}1.98 \\
6.34 \\
3.03 \\
2.13\end{array}$ & $\begin{array}{l}1.10 \\
6.15 \\
2.13 \\
1.27\end{array}$ & $\begin{array}{l}4.05 \\
6.10 \\
5.28 \\
4.30\end{array}$ & 381 \\
\hline
\end{tabular}

increased suddenly from low normal and remained elevated. The changes could not be related to therapy.

The glycine tolerance test of two patients with endocrine disturbances, one (Table II, No. 5) with hypothyroidism and the other (Table II, No. 6) with acromegaly and hypermetabolism, showed very high plasma and red cell glycine following injection, with an abnormally slow decline thereafter. Fasting blood glycine was also abnormally high. In Case No. 7 (hypometabolism and nutritional hypoproteinemia) plasma glycine rose markedly after injection. The subsequent decline, however, was essentially normal.

Two diabetics, both insulin treated, showed low normal plasma glycine.

Elevated whole blood and red cell glycine was observed in a case of Addison's disease with scleroderma.

Diseases of muscle: Four patients with myopathies were studied. One of two cases of myasthenia gravis showed normal blood glycine and $\alpha$ amino $\mathrm{N}$; he was receiving prostigmine therapy. In the other individual (No. 74), who was largely bedridden, glycine and $\alpha$ amino $\mathrm{N}$ were elevated. She had been taking methyltestosterone orally for nine months. Unfortunately these subjects were not studied prior to treatment.

One subject with progressive muscular dystrophy and hypometabolism (No. 76) showed low normal amino $\mathrm{N}$ and glycine levels one and a half years ago. After stilbestrol therapy for several months, his blood glycine became elevated. Glycine tolerance, however, was normal.

Patient B. K. (No. 51), with myopathy and hyperthyroidism, discussed before, showed low blood and plasma glycine. An oral glycine tolerance curve, reported in a previous communication (16), was abnormally flat.

Rheumatoid arthritis: This group comprised six cases, all with active disease. One patient No. 118) had moderate anemia and spiking fever. Low plasma glycine was observed in two (Nos. 118,129 ) one of whom (No. 118; Table II, Nos. $10,11)$ showed remarkably abnormal glycine tolerance curves. Not only were they relatively flat (Figures 1 and 2) but also they returned practically to the pre-injection values, in contrast to the 
other subjects. Furthermore, glycine administered the night before the test did not affect the pattern of response. The urinary glycine of this patient during the tolerance test was not significantly different from that of other individuals. Administration of glycine (10 gms. a day for four days orally, 30 gms. orally or 8 gms. intravenously) did not influence his creatinine or creatine excretion.

Ten minutes following the first glycine injection, the patient suddenly experienced remarkable "loosening" of the joints with painless mobility for the first time in two weeks. After eight hours, the pain and limitation of motion returned gradually. These observations could not be repeated.

Blood diseases: Two subjects with erythremia had elevated erythrocyte glycine; in one, receiving

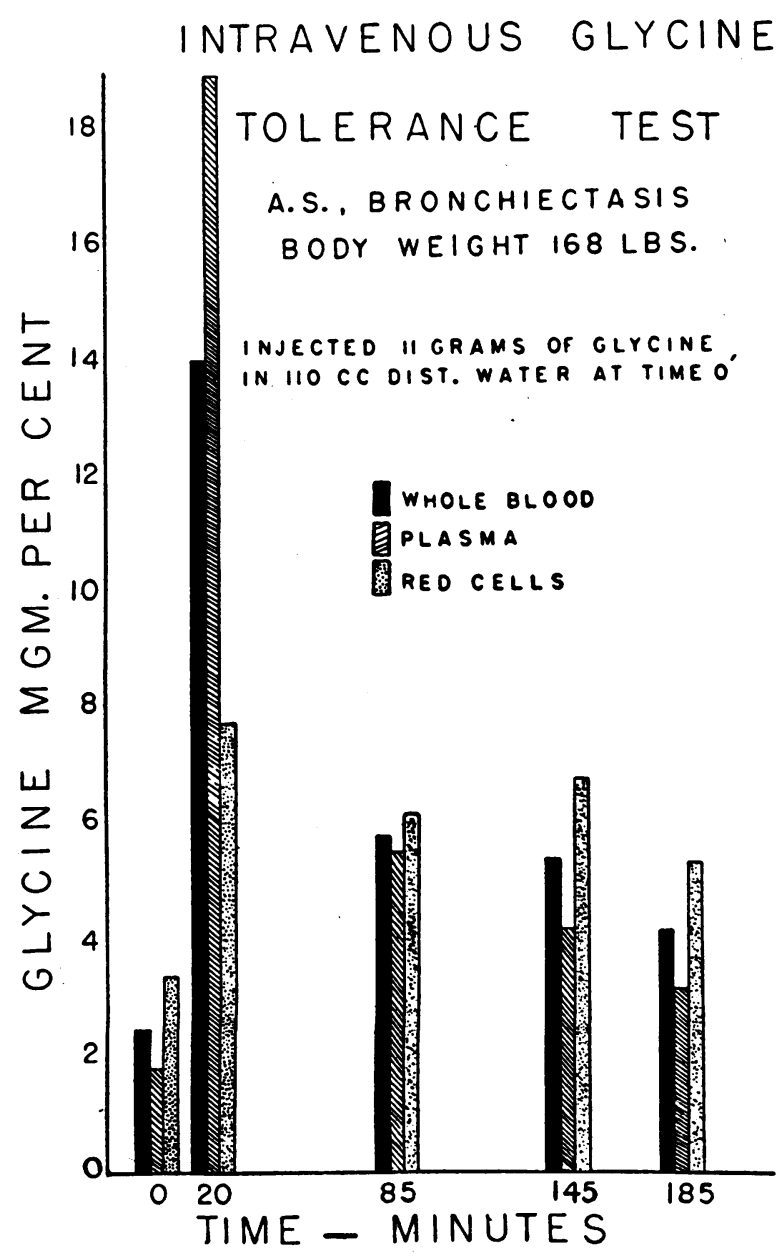

Fig. 1. Effects of Intravenously Administered GLYCINE urethane, the plasma value was low. Elevated red cell glycine was also found in two patients with chronic myelogenous leukemia. In one (No. 92) the concentration decreased in both blood and plasma after the leucocytes had dropped from 230,000 to $12,900 / \mathrm{mm}$. following treatment with urethane. $^{3}$

One patient with untreated pernicious anemia showed normal glycine values.

Miscellaneous: High red cell glycine and amino $\mathrm{N}$ were observed in a case of pemphigus vulgaris (No. 81) (under nirvanol treatment); red cell glycine was also elevated in disseminated lupus and urticaria. Significantly low values were observed in two cases of ulcerative colitis with malnutrition (Nos. 106, 107). In one (No. 106) plasma glycine was low whereas the level in whole blood was normal. In the other subject (No. 107) blood and red cell glycine were low but the concentration in the plasma was normal. High red cell glycine levels were observed in a case of ruptured intervertebral disc (No. 94), and in one patient with carcinoma of the pancreas (No. 103).

\section{Effects of intravenously administered glycine}

No untoward reactions occurred following intravenous glycine. Within ten minutes the subjects generally experienced warmth and flushing of the face, and sometimes paresthesiae in fingers and toes. Because glycine is said to affect the kidneys of animals adversely (19), the urine was examined in all subjects during and after the test, but no changes were observed.

Following glycine infusion, blood values changed rather uniformly (Figure 1 is typical). Twenty minutes after injection plasma and red cell glycine became markedly elevated, the former to a greater extent than the latter. Subsequently plasma glycine declined gradually, sometimes falling to lower values than whole blood glycine since red cell glycine lagged behind plasma changes and, in some cases, remained elevated (Table II, No. 10). In only one subject (Table II, Nos. 10, 11) did plasma glycine return to the pre-injection level during the period of observation.

The height of the 20-minute rise in blood and plasma glycine seemed to be related to the fasting values; this relationship was not apparent for erythrocyte glycine. 


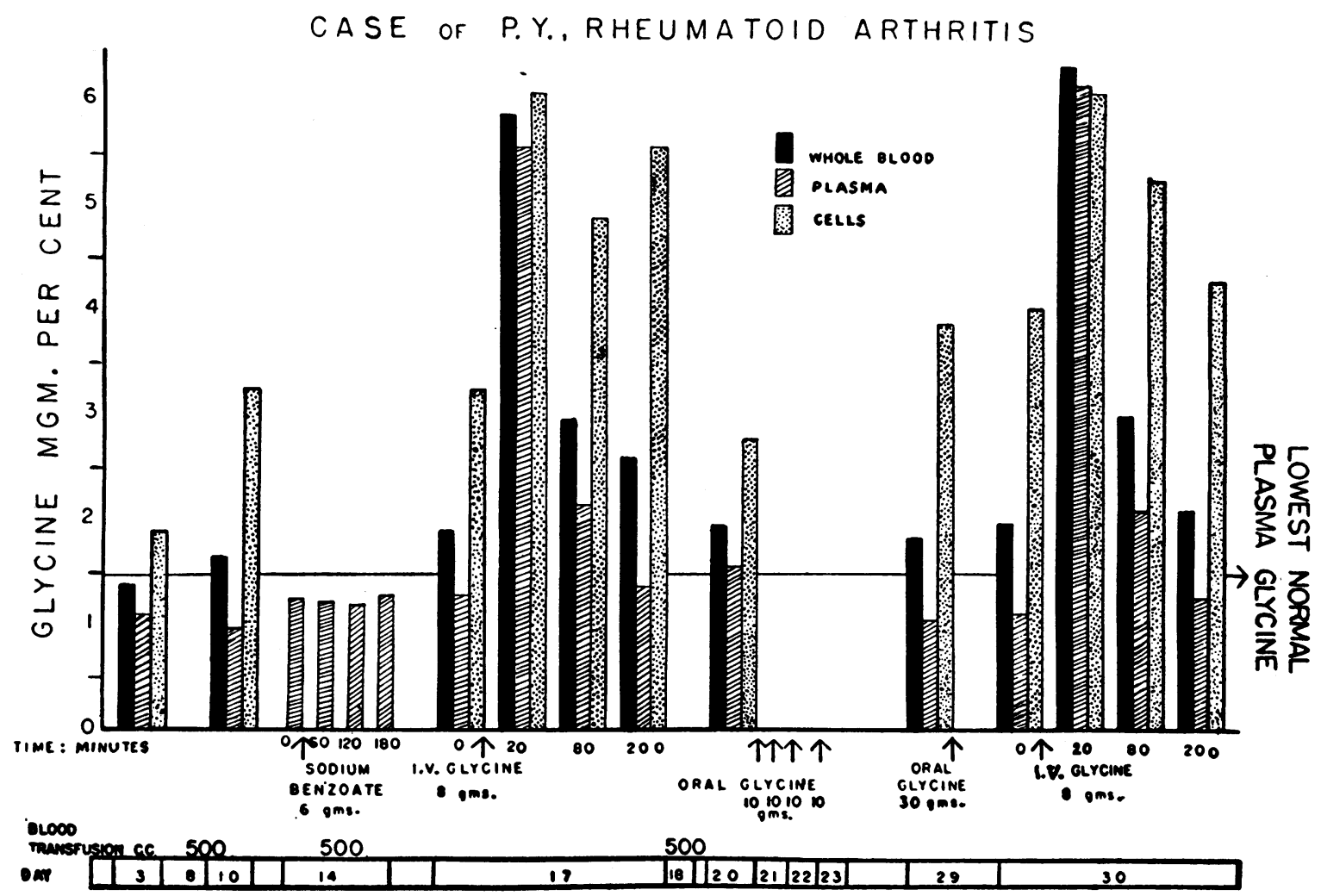

Fig. 2. Intravenous Glycine Tolerance Test

Total glycine excreted during the test, always less than a gram, varied widely and was unrelated to the blood glycine curve.

The slow rise in erythrocyte glycine compared with plasma glycine may be due either to its slow diffusion into red cells or to its early transformation or conjugation within the cells. Experiments exploring these possibilities are presented below.

Oxalated blood, divided into four samples, was treated as follows:

Sample 1: $24 \mathrm{cc}$. were mixed with $0.5 \mathrm{cc}$. of an aqueous glycine solution (1.16 gms. per $100 \mathrm{cc}$.). The mixture was immediately analyzed for blood, "plasma," and red cell glycine.

Sample 2: $24 \mathrm{cc}$. were mixed with $0.5 \mathrm{cc}$. physiological saline; an aliquot was similarly analyzed.

Sample 3: to $12.8 \mathrm{cc}$. of plasma was added $0.5 \mathrm{cc}$. glycine solution; glycine was determined immediately.

Sample 4: to $12.8 \mathrm{cc}$. plásma was added $0.5 \mathrm{cc}$. isotonic sodium chloride solution and the mixture was analyzed.

Determinations were repeated two and four hours later on samples of the four mixtures which were incubated at $37^{\circ} \mathrm{C}$. with frequent shaking. The results (Table III) show that in Sample 2 the glycine of blood, plasma and erythrocytes rose slowly during incubation. The highest increase occurred in the cells where, it seemed, some glycine was either liberated from a conjugated form or was otherwise evolved. In Sample 1 the artificially augmented plasma glycine declined slightly while cell glycine increased considerably. The total glycine of the mixture, however, rose only by an amount roughly equal to that observed in Sample 2.

\section{TABLE III}

Changes in plasma and red cell glycine in vitro

Hematocrit was $\mathbf{4 5}$ per cent packed cells and it remained constant. All values expressed in mgm. per cent. Incubated at $37^{\circ} \mathrm{C}$.

\begin{tabular}{|c|c|c|c|c|c|c|c|c|}
\hline \multirow{2}{*}{$\begin{array}{c}\text { In- } \\
\text { cuba- } \\
\text { tion } \\
\text { time }\end{array}$} & \multicolumn{3}{|c|}{$\begin{array}{c}\text { Sample 1 } \\
\text { Blood +glycine }\end{array}$} & \multicolumn{3}{|c|}{$\begin{array}{c}\text { Sample } 2 \\
\text { Blood +saline }\end{array}$} & \multirow{2}{*}{$\begin{array}{l}\text { Sample } 3 \\
\text { Plasma } \\
\text { +glycine }\end{array}$} & \multirow{2}{*}{$\begin{array}{c}\text { Sample } \\
\text { Plasma } \\
\text { tsaline }\end{array}$} \\
\hline & Blood & Plasma & Cells & Blood & Plasma & Cells & & \\
\hline $\begin{array}{c}\text { hrs. } \\
0 \\
2 \\
4\end{array}$ & $\begin{array}{l}25.2 \\
25.6 \\
27.2\end{array}$ & $\begin{array}{l}41.9 \\
40.2 \\
38.6\end{array}$ & $\begin{array}{r}4.69 \\
7.71 \\
13.20\end{array}$ & $\begin{array}{l}2.17 \\
3.08 \\
3.57\end{array}$ & $\begin{array}{l}1.75 \\
1.99 \\
2.34\end{array}$ & $\begin{array}{l}2.68 \\
4.41 \\
5.09\end{array}$ & $\begin{array}{l}41.7 \\
41.9 \\
43.4\end{array}$ & $\begin{array}{l}1.91 \\
1.72 \\
1.94\end{array}$ \\
\hline
\end{tabular}




\section{DISCUSSION}

The relatively normal plasma glycine concentrations in acute infectious hepatitis and cirrhosis of the liver are in accord with the normal total amino acid levels reported in these diseases (20-24). Only in complete hepatectomy (25) or severe liver damage (20) as in acute yellow atrophy (26-28) are amino acid values increased. The low glycine found in our case of subacute yellow atrophy might be referable to inability to synthesize this "non-essential" amino acid or to malnutrition, as suggested by the low plasma glycine observed in chronic ulcerative colitis with malnutrition. However, blood amino acid concentrations in experimental nutritional hypoproteinemia are normal (29) while our case of nutritional hypoproteinemia (Table I, Nos. 67-71) showed exceptionally high blood and plasma glycine levels after a low initial value.

The normal glycine tolerance in liver disease also is in agreement with the experience of others who found amino acid-loading tests useless in the diagnosis of liver disease $(20,23)$.

The high glycine concentrations in chronic glomerulonephritis is not related to the hypoproteinemia, the hyperaminoacidemia $(30,31)$ or the nitrogen retention found in kidney disease. Nor can the glycinemia be explained by inadequate urinary glycine excretion since the amount thus eliminated is usually small. It is possible that the metabolism of glycine in the diseased kidney is disturbed in view of the function of this organ in elaborating guanidoacetic acid from glycine and arginine $(7,32)$. The normal glycine tolerance in two nephritics, one with the nephrotic syndrome, is in accord with the reported undisturbed utilization of glycine in nephrosis (33).

The literature on blood amino acids in endocrine disturbances is extensive $(34,35)$. Thyroidectomy or thiouracil lowers blood amino acids in rats whereas tissue amino acids are unaffected. Okada and Hayashi (36), on the other hand, found no such alterations following thyroidectomy.

Our observations indicate that hypometabolism tends to be associated with high blood glycine and normal $\alpha$ amino $N$. The abnormally elevated plasma amino acid curve reported by Witts (21) after glycine administration in a patient with myxedema, is in accord with our results with the gly- cine tolerance test in hypometabolism. Presumably the tissues of these cases with high fasting plasma glycine are also rich in glycine and accordingly are less able to take up additional amounts of the amino acid.

Contrary to what might be expected from the above, glycine values were generally normal in hypermetabolism. This is in agreement with the blood amino $\mathrm{N}$ findings of Maddock et al. (37) but is in contrast to the elevated values reported for the plasma, liver, and skeletal muscles of rats treated with thyroxine (35). The low glycine and low oral glycine tolerance test (16) in one case of hyperthyroidism with severe myopathy and creatinuria may be related to this complication.

The elevated glycine in the acromegalic may be referable to the anabolic effect of the growthpromoting hormone of the pituitary on protein metabolism although this hormone is said to lower the blood amino acids (38-40).

The high glycine observed in a case of Addison's disease with hypotension and hypochloremia despite DOCA and salt therapy is noteworthy in view of decreased plasma amino acids in adrenalectomized rats, which increased markedly after administration of cortical extract (35).

The relation between glycine and creatine and the role of the latter in the metabolism of muscle have been studied extensively $(7,11,12,41-55)$. It is likely that in the myopathy of thyrotoxicosis (44) and in myopathies in general (34) there is no impairment of creatine synthesis, but rather of creatine storage and utilization. This concept is compatible with the low glycine values obtained in the patient with thyrotoxicosis and myopathy and in the subject with progressive muscular dystrophy if we assume that excessive creatinuria serves to deplete glycine stores faster than the amino acid can be synthesized in the body.

The elevated glycine and total blood amino acids in one patient with myasthenia gravis who was receiving methyltestosterone may be referable to the anabolic effects of this hormone (56).

Little which is non-speculative can be said concerning the strikingly low glycine in certain cases of rheumatoid arthritis. It is noteworthy that the glycine content of elastin, an important protein constituent of ligaments and tendons, is 25.5 per cent (57). The low tolerance curve and rapid clearance of injected glycine from the plasma of 
one subject suggest an undue avidity of the tissues for this amino acid or its rapid destruction. The latter seems more likely since large amounts of glycine administered twelve hours prior to the test had no effect on the tolerance. In addition a hippuric acid test, to be reported elsewhere (58), revealed that hippuric acid excretion following ingestion of benzoate was subnormal in this patient. Further investigation of the role of glycine in this disease is in progress.

The high erythrocyte glycine in both polycythemia vera and myelogenous leukemia was striking. The decrease in glycine in myelogenous leukemia consequent to urethane therapy and the strikingly low plasma glycine in the polycythemic, who, under treatment with the same chemical, showed at the same time a significantly high erythrocyte glycine warrant further study of glycine metabolism and the effects of urethane in those blood dyscrasias.

Following the intravenous administration of 1 gm. of glycine per $15 \mathrm{lbs}$. of body weight plasma glycine rises to between 14 and $38 \mathrm{mgm}$. per cent. Assuming a plasma volume of 3.5 liters in patient A. S. the injection of $11 \mathrm{gms}$. of the amino acid should theoretically have resulted in a plasma glycine of about $300 \mathrm{mgm}$. per cent if all the glycine had remained in the plasma. After 20 minutes, only about 7 per cent of the injected amino acid could be accounted for in this patient's blood. These discrepancies in view of the relatively insignificant urinary glycine, indicate a rapid uptake of the amino acid by the tissues. Similar observations, based upon total amino $\mathrm{N}$ determination, have been made after administration of glycine or of amino acid mixtures $(10-13,59)$. In this respect it is significant that the amino acid levels in muscles and kidney remain high for more than three hours after glycine injection (60), whereas liver amino acid (60) and blood glycine had already returned almost to normal. Furthermore, in our experiments with benzoate-glycine conjugation (58), we observed that the ingestion of 10 gms. of glycine 12 hours prior to benzoate administration increases the amount of hippuric acid

- formed, despite the fact that plasma glycine is normal at the time of the test. The supplementary glycine probably was present in the tissues, either free or bound in an easily available form.

After the ingestion of protein plasma and erythro- cyte amino acids rise, the latter lagging behind the former and persisting for several hours even when plasma amino acid was returning toward normal (61). Similar observations regarding glycine have been described after oral administration of this amino acid $(16,62)$. The same results are obtained following intravenous glycine. On the basis of our in vitro experiments this lag is best interpreted as being due to a slow diffusion of glycine into and out of the erythrocytes.

\section{SUM MARY}

Blood glycine and $\alpha$ amino $\mathrm{N}$ have been studied in various pathological states. Low blood glycine was observed in one case of subacute yellow atrophy, one subject with hyperthyroidism with myopathy, and in two cases of ulcerative colitis. The lowest values were observed in subjects with rheumatoid arthritis.

A distinct tendency toward elevated glycine, particularly in the erythrocytes, was found in some patients with liver disease, with chronic glomerulonephritis, with hypometabolism, with polycythemia vera, and with leukemia.

No relation was evident between the concentrations of glycine, total $\alpha$ nitrogen, plasma protein, and blood non-protein nitrogen.

The intravenous administration of glycine results in a rapid rise and subsequent decline in both plasma and red cell glycine concentration. The latter lags somewhat behind the former, which, on the basis of in vitro studies, is interpreted as being due to slow diffusion of glycine into and out of the erythrocyte.

Certain abnormalities in the glycine tolerance curve were observed in a few pathological subjects.

\section{BIBLIOGRAPHY}

1. Shemin, D., The biological conversion of 1-serine to glycine. J. Biol. Chem., 1946, 162, 297.

2. Lenthardt, F., Uber Hippursäurebildung aus Glutamin. Ztschr. f. physiol. Chem., 1941, 270, 113.

3. Ratner, S., Nocito, V., and Green, D. E., Glycine oxidase. J. Biol. Chem., 1944, 152, 119.

4. Barker, H. A., and Elsden, S. R., Carbon dioxide utilization in the formation of glycine and acetic acid. J. Biol. Chem., 1947, 167, 619.

5. Barker, H. A., and Beck, J. V., The fermentative decomposition of purines by clostridium acidi-urici and clostridium cylindrosporum. J. Biol. Chem., 1941, 141, 3. 
6. Sonne, J. C., Buchanan, J. M., and Delluva, A. M., Biological precursors of uric acid carbon. J. Biol. Chem., 1946, 166, 395.

7. Bloch, K., and Schoenheimer, R., Biological precursors of creatine. J. Biol. Chem., 1941, 138, 167.

8. Waelsch, H., and Rittenberg, D., Glutathione. I. The metabolism of glutathione studied with isotopic glycine. J. Biol. Chem., 1941, 139, 761.

9. Shemin, D., and Rittenberg, D., The utilization of glycine for the synthesis of a porphyrin. J. Biol. Chem., 1945, 159, 567.

10. Shemin, D., and Rittenberg, D., The biological utilization of glycine for the synthesis of protoporphyrin of hemoglobin. J. Biol. Chem., 1946, 166, 621.

11. Boothby, W. M., Myasthenia gravis: Eighth report. Tr. A. Am. Physicians, 1936, 51, 188.

12. Cooke, A. M., and Passmore, R., Observations on treatment of myasthenia gravis. Quart. J. Med., 1936, 5, 21.

13. Gubner, R., di Palma, J. R., and Moore, E., Specific dynamic action as a means of augmenting peripheral blood flow. Use of amino-acetic acid. Am. J. M. Sc., 1947, 213, 46.

14. Shemin, D., and Rittenberg, D., The life span of the human red blood cell. J. Biol. Chem., 1946, 166, 627.

15. London, I. M., Shemin, D., and Rittenberg, D., Application of the isotope technique to the study of the rates of formation of blood constituents in man: J. Clin. Invest., 1947, 26, 1188.

16. Gutman, G. E., and Alexander, B., Studies on amino acid metabolism. I. Blood glycine and alanine and their relationship to the total amino acids in normal subjects. J. Biol. Chem., 1947, 168, 527.

17. Alexander, B., Landwehr, G., and Seligman, A. M. A specific micromethod for the colorimetric determination of glycine in blood and urine. J. Biol. Chem., 1945, 160, 51.

18. Van Slyke, D. D., Dillon, R. T., MacFadyen, D. A., and Hamilton, P., Gasometric determination of carbonyl groups in free amino acids. J. Biol. Chem., 1941, 141, 627.

19. Hay, E. C., Hepato- and nephrotoxic effect of glycine. Federation Proc., 1947, 6, 125.

20. Kirk, E., Amino acid and ammonia metabolism in liver diseases. Acta med. Scandinav. Suppl., 1936, 77, 89.

21. Witts, L. J., Observations on the metabolism of amino acids in health and disease. Quart. J. Med., 1929, $22,477$.

22. Caccuri, S., and Chiarello, A., Arch. de mal. l'app. digestife, 1924, 24, 840. (Cited by Kirk, E. [20].)

23. Erf, L. A., and Rhoads, C. P., The glycine tolerance test in sprue and pernicious anemia. J. Clin. Invest., 1940, 19, 409.

24. Weicker, B., ther den Nachweis gestörter Teilfunktionem als Grundlage funktioneller Leberdiagnostik. Ztschr. f. d. ges. exper. Med., 1932, 81, 481.

25. Bollman, J. L., Mann, F. C., and Magath, T. B., Studies on the physiology of the liver. XV. Ef- fect of total removal of the liver on deaminization. Am. J. Physiol., 1926, 78, 258.

26. Feigl, I., and Luce, H., Neue Untersuchungen über akute gelbe Leberatrophie. I. Uber den Reststickstoff des Blutes und seine Komponenten. Weitere Beiträge zur vergleichenden Pathologie des Aminosāure Spiegels im Blute. Biochem. Ztschr., 1917, 79, 162.

27. Stadie, W. C., and Van Slyke, D. D., Effect of acute yellow atrophy on metabolism and on composition of liver. Arch. Int. Med., 1920, 25, 693.

28. Rabinowitch, I. M., Biochemical findings in a rare case of acute yellow atrophy of the liver. With particular reference to the origin of urea in the body. J. Biol. Chem., 1929, 83, 333.

29. Goettsch, E., Lyttle, J. D., Grim, W. M., and Dunbar, P., Amino acid studies. I. Plasma amino acid retention in the hypoproteinemic dog as evidence of impaired liver function. J. Biol. Chem., 1942, 144, 121.

30. Kirk, E., Amino nitrogen changes of the blood in nephritis. J. Clin. Invest., 1933, 12, 1091.

31. Snoo, K. de, Over het aminozuur gehalte van het blood. Dissertatie. Utrecht, 1920.

32. Borsook, H., and Dubnoff, J. W., The formation of glycine in animal tissues. J. Biol. Chem., 1941, 138, 389.

33. Kirk, E., The ability of nephritic patients to deaminize and form urea from ingested glycine. J. Clin. Invest., 1935, 14, 136.

34. Peters, J. P., and Van Slyke, D. D., Quantitative Clinical Chemistry. Interpretations. Vol. I. The Williams \& Wilkins Co., Baltimore, 1946.

35. Friedberg, F., and Greenberg, D. M., Endocrine regulation of amino acid levels in blood and tissues. J. Biol. Chem., 1947, 168, 405.

36. Okada, S., and Hayashi, T., Studies on the aminoacid nitrogen content of the blood. J. Biol. Chem., 1922, 51, 121.

37. Maddock, W. G., Pederson, S., and Coller, F. A., Studies of the blood chemistry in thyroid crisis. J. A. M. A., 1937, 109, 2130.

38. Fraenkel-Conrat, J., Fraenkel-Conrat, H., and Evans, H. M., Effects of purified pituitary preparations on the nonprotein nitrogen constituents of blood. Am. J. Physiol., 1942, 137, 200.

39. Lukens, F. D. W., Pituitary-diabetes. Am. J. M. Sc., 1946, 212, 229.

40. Teel, H. M., and Watkins, $O$., The effect of extracts containing the growth principle of the anterior hypophysis upon the blood chemistry of dogs. Am. J. Physiol., 1929, 89, 662.

41. Borsook, H., and Dubnoff, J. W., Methylation of guanidoacetic acid by homocystine plus choline with rat liver slices. J. Biol. Chem., 1945, 160, 635.

42. Baker, Z., and Miller, B. F., Studies on the metabolism of creatine and creatinine. III. Formation of creatine by isolated tissues. J. Biol. Chem., 1940, 132, 233. 
43. Borsook, H., and Dubnoff, J. W., Creatine formation in liver and kidney. J. Biol. Chem., 1940, 134, 635.

44. Thorn, G. W., and Eder, H. A., Studies on chronic thyrotoxic myopathy. Am. J. of Med., 1946, 1, 583.

45. Wang, E., Clinical and experimental investigations on the creatine metabolism. Acta med. Scandinav. Suppl., 1939, 105, 1.

46. Wilkins, L., and Fleischmann, W., Effect of thyroid on creatine metabolism with a discussion of the mechanism of storage and excretion of creatine bodies. J. Clin. Invest., 1946, 25, 360.

47. Thomsen, A., The glycine synthesis in patients with progressive muscular dystrophy. J. Clin. Invest., 1937, 16, 231.

48. Milhorat, A. T., and Wolff, H. G., Studies in diseases of muscle. I. Metabolism of creatine and creatinine in progressive muscular dystrophy. Arch. Neurol. \& Psychiat., 1937, 38, 992.

49. Milhorat, A. T., and Wolff, H. G., Metabolism of creatine and creatinine in muscle disease. Ann. Int. Med., 1936, 9, 834.

50. Boothby, W. M., Myasthenia gravis : effect of treatment with glycine and ephedrine. Arch. Int. Med., 1934, 53, 39.

51. Milhorat, A. T., and Wolff, H. G., Studies in diseases of muscle. III. Metabolism of creatine and creatinine in myasthenia gravis, including a study of the excretion of nucleosides and nucleotides. Arch. Neurol. \& Psych., 1938, 39, 354.

52. Reinhold, J. G., and Kingsley, G. R., The chemical composition of voluntary muscle in muscle disease : a comparison of progressive muscular dystrophy with other diseases together with a study of the effect of glycine and creatine therapy. J. Clin. Invest., 1938, 17, 377.

53. Brand, E., Harris, M. M., Sandberg, M., and Ringer, A. I., Studies on the origin of creatine. Am. J. Physiol., 1929, 90, 296.
54. Harris, M. M., and Brand, E., Metabolic and therapeutic studies in the myopathies with special reference to glycine administration. J. A. M. A., 1933, 101, 1047.

55. Kostakow, G., and Slauck, A., Die Glykokollbehandlung der progressiven Muskeldystrophie. Zugleich ein Beitrag zur Herkunft des Kreatins. Deutsches Arch. f. klin. Med., 1933, 175, 25.

56. Wilkins, L., and Fleischmann, W., Studies on the creatinuria due to methylated steroids. J. Clin. Invest., 1945, 24, 21.

57. Griffith, W. H., and Lewis, H. B., Studies in the synthesis of hippuric acid in the animal organism. VI. The influence of the protein of the diet on the synthesis and rate of elimination of hippuric acid after the administration of benzoates. J. Biol. Chem., 1923, 57, 697.

58. de Vries, A., and Alexander, B., Studies on amino acid metabolism. III. Plasma glycine concentration and hippuric acid formation following the ingestion of benzoate. J. Clin. Invest., 1948, 27, 665.

59. Friedberg, F., and Greenberg, D. M., Partition of intravenously administered amino acids in blood and tissues. J. Biol. Chem., 1947, 168, 411.

60. Lyttle, J. D., Goettsch, E., Greeley, D. M., Grim, W. M., and Dunbar, P., Amino acid studies. II. Plasma amino retention as evidence of impaired liver function. Investigations in children with nephrosis and liver disease. J. Clin. Invest., 1943, 22, 169.

61. Folin, O., and Berglund, H., The retention and distribution of amino acids with especial reference to urea formation. J. Biol. Chem., 1922, 51, 395.

62. Christensen, H. N., Cooper, P. F., Jr., Johnson, R. D., and Lynch, E. L., Glycine and alanine concentrations of body fluids; experimental modification. $\mathrm{J}$. Biol. Chem., 1947, 168, 191. 